\title{
Establishment and characterization of a murine mucosal mast cell culture model
}

\author{
Aya Kakinoki 1, Tsuyoshi Kameo ${ }^{1}$, Shoko Yamashita ${ }^{2}$, Kazuyuki Furuta ${ }^{2}$, and Satoshi Tanaka 3,* \\ 1 Department of Immunobiology, Faculty of Pharmacy and Pharmaceutical Sciences, Okayama University, \\ Tsushima naka 1-1-1, Kita-ku, Okayama, 700-8530, Japan. \\ 2 Department of Immunobiology, Okayama University Graduate School of Medicine, Dentistry, and \\ Pharmaceutical Sciences, Tsushima naka 1-1-1, Kita-ku, Okayama, 700-8530, Japan. \\ 3 Department of Pharmacology, Division of Pathological Sciences, Kyoto Pharmaceutical University, \\ Misasagi Nakauchi-cho 5, Yamashina-ku, Kyoto, 607-8414, Japan. \\ * Correspondence: tanaka-s@mb.kyoto-phu.a.jp; Tel.: +81-75-595-4667
}

\begin{abstract}
Accumulating evidence suggests that mast cells should play critical roles in disruption and maintenance of intestinal homeostasis, although it remains unknown how they affect local microenvironment. Interleukin-9 (IL-9) was found to play critical roles in intestinal mast cell accumulation induced in various pathological conditions, such as parasite infection and oral allergeninduced anaphylaxis. Newly recruited intestinal mast cells trigger inflammatory responses and damage epithelial integrity through release of a wide variety of mediators including mast cell proteases. We established a novel culture model (mucosal mast cell-like cultured mast cells, MMClike MCs), in which murine IL-3-dependent bone marrow-derived cultured mast cells (BMMCs) were further cultured in the presence of stem cell factor and IL-9. In MMC-like MCs, drastic up-regulation of Mcpt1 and Mcpt2 was found. Although histamine storage and tryptase activity were significantly downregulated in the presence of SCF and IL-9, it was entirely reversed when mast cells were cocultured with a murine fibroblastic cell line, Swiss 3T3. MMC-like MCs underwent degranulation upon IgE-mediated antigen stimulation, which was found to less sensitive to lower concentrations of IgE in comparison with BMMCs. This model might be useful for investigation of the spatiotemporal changes of newly recruited intestinal mast cells.
\end{abstract}

Keywords: mast cell; IL-9; chymase; histamine; ATP

\section{Introduction}

Intestinal and respiratory tracts are constantly exposed to a wide variety of stimulatory factors and are in a continuous state of change. Immune cells located at these tracts have to adapt themselves to these changes in a timely manner. Mast cells are one of the most suitable immune cells that regulate immune responses at such interfaces because they express a diverse array of surface receptors and undergo flexible local transdifferentiation $[1,2]$. They were found not only to trigger inflammatory responses but also to be involved in immune suppression [3]. Accumulating evidence suggests that intestinal mast cells play critical roles in parasite expulsion through their multiple functions including regulation of epithelial and endothelial functions, and modulation of innate and adaptive immunity [4-6].

Interleukin-9 (IL-9), which was also found to be one of the critical mediators for worm expulsion, was first identified as a mast cell growth factor [7]. IL-9 transgenic mice exhibited rapid expulsion of the intestinal nematodes and local mastocytosis in epithelial layer of the gut, trachea, and kidney [810]. The number of intestinal mast cells were unchanged in the gene-targeted mice lacking IL-9 or IL9 receptor $\alpha$ chain, whereas oral antigen-induced accumulation of intestinal mast cells was impaired in these mice [11, 12]. These findings indicate that IL-9 should trigger intestinal mastocytosis upon parasite infection and newly recruited mast cells should make significant contribution to worm 
expulsion. IL-9 was found to enhance stem cell factor (SCF)-mediated proliferation of murine bone marrow-derived cultured mast cells, although IL-9 alone could not support mast cell growth and survival [13]. It remains largely unknown how transdifferentiation of intestinal mast cells should occur under the influence of IL-9 and SCF.

IL-3-dependent bone marrow-derived cultured mast cells (BMMCs) have been investigated as a useful model of murine immature mast cells. IL-3 was also found to play critical roles in parasite expulsion and intestinal mastocytosis [14]. Because BMMCs are highly capable for further differentiation into mature mast cells, local reconstitution of BMMCs in recently developed mast celldeficient mice has been used as one of the best suitable approaches to clarify the functions of tissue mast cells [15]. We previously established a modified co-culture method of BMMCs using murine fibroblastic cell line, Swiss 3T3, which shared many characteristics with murine cutaneous mast cells $[16,17]$. We developed here a novel culture model, in which BMMCs were further cultured in the presence of IL-9 and SCF. This model at least partly reflected the characteristics of intestinal mast cells and provided significant insights into maturation of newly recruited mast cells in intestinal tissues.

\section{Results}

2.1. Combination of IL-9 and SCF induced expression of Mcpt1 and Mcpt2 and depleted histamine in murine BMMCs

Accumulating evidence suggests that SCF plays critical roles in growth and survival of murine tissue mast cells, which is enhanced by IL-9 in mucosal tissues. We, therefore, characterized the changes of murine BMMCs in the presence of SCF and IL-9. Expression of Mcpt1 and Mcpt2 was drastically induced during the culture period in the presence of SCF and IL-9, which is consistent with the previous findings [13], whereas that of Mcpt5 and Cpa3 was upregulated and maintained (Fig. 1a-1d). It was noteworthy that a drastic downregulation of $H d c$, which encodes the enzyme responsible for histamine synthesis, was observed (Fog. 1e). We previously demonstrated that Ptgr1, which encodes the enzyme involved in inactivation of the eicosanoids, was expressed in the mucosal mast cells, not in the connective tissue-type mast cells in murine stomach [18]. Expression of Ptgr1, was found to be moderately upregulated in our system (Fig. 1f). Surface expression levels of FceRI and c-kit were significantly decreased in the presence of SCF and IL-9 (Fig. 1g and 1h).

We then measured the enzymatic activities of the cultured mast cells. Chymotryptic activity was significantly increased in BMMCs cultured in the presence of SCF and IL-9 for 12 days (mucosal mast cell-like mast cells, MMC-like MCs), whereas tryptic activity was down-modulated (Fig. 2a and 2b). In agreement with the expression levels of $H d c$, histamine synthesis was drastically suppressed in the presence of SCF and IL-9 (Fig. $2 \mathrm{~g}$ and $2 \mathrm{~h}$ ). Because tissue mast cells are often located next to cells expressing the membrane-bound form of SCF, we performed the co-culture with a murine fibroblastic cell line, Swiss 3T3, in the presence of SCF and IL-9 and investigated the characteristics of the co-culture mast cells. The presence of fibroblasts enhanced the induction of chymotryptic activity (Fig. 2d). Regarding the tryptic activity and histamine synthesis, the presence of fibroblasts reversed the actions of SCF and IL-9(Fig. 2e, 2i and 2j). 

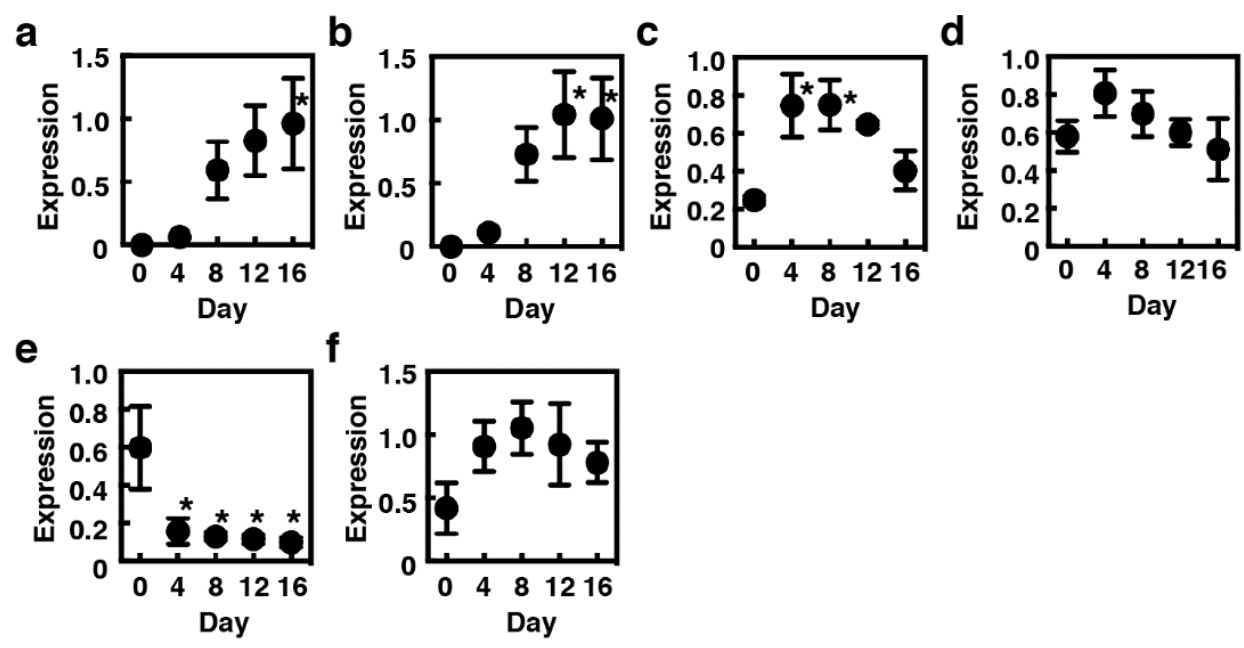

g
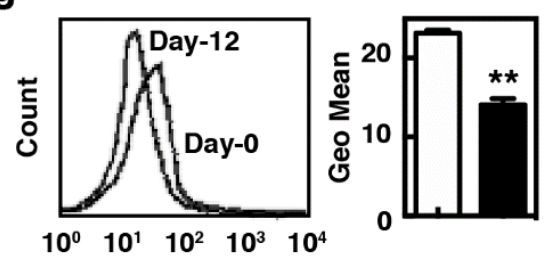

h
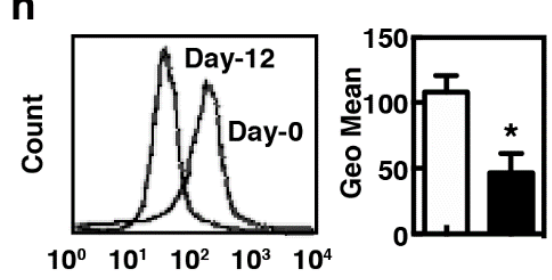

Figure 1. (a-f) BMMCs were cultured in the presence of $10 \mathrm{ng} / \mathrm{ml} \mathrm{IL-9}$ and $30 \mathrm{ng} / \mathrm{ml}$ SCF for 16 days. Expression levels of mRNA of Mcpt1 (a), Mcpt2 (b), Mcpt5 (c), Cpa3 (d), Hdc (e), and Ptgr1 (f) were measured by quantitative RT-PCR. The expression levels were normalized by measuring mRNA expression of Gapdh. The values are expressed as the means \pm SEM $(n=3)$. Multiple comparisons were performed using one-way ANOVA with the Dunnett posttest. Values with ${ }^{*} p<0.05$ are regarded as significant (vs. Day-0). (g, h) Surface expression levels of FceRI (g) and c-kit (h) of BMMCs (Day-0, open columns) and MMC-like MCs (Day-12, closed columns) were measured by flow cytometry as described in the Materials and Methods. The mean fluorescence intensities are shown as the means \pm $\operatorname{SEM}\left(\mathrm{n}=3\right.$, right panels). Statistical analysis was performed using Student's t test. Values with ${ }^{*} p<0.05$ and ${ }^{* *} p<0.01$ are regarded as significant.

2.2. Antigen-induced degranulation was attenuated in MMC-like MCs when they were sensitized with lower concentartions of IgE

Previous studies suggested that IL-9 alone should not be able to form mast cell population from hematopoietic stem cells in the bone marrow but could support the expansion and maturation of mucosal mast cell population [13]. We then compared the characteristics of two model populations, BMMCs as a newly recruited immature population, and MMC-like MCs as a more differentiated mucosal population. MMC-like MCs showed a similar profile to that of BMMCs in degranulation upon IgE-mediated antigen stimulation when they were sensitized with $1 \mu \mathrm{g} / \mathrm{ml}$ of IgE, whereas the levels of degranulation were significantly decreased in MMC-like MCs when they were sensitized with $10 \mathrm{ng} / \mathrm{ml}$ IgE (Fig. 3a and 3b). Decreases in the levels of degranulation were also found in MMClike MCs when they were stimulated with thapsigargin and A23187 (Fig. 3c). 
a

b

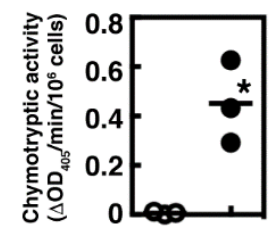

b c

d

e
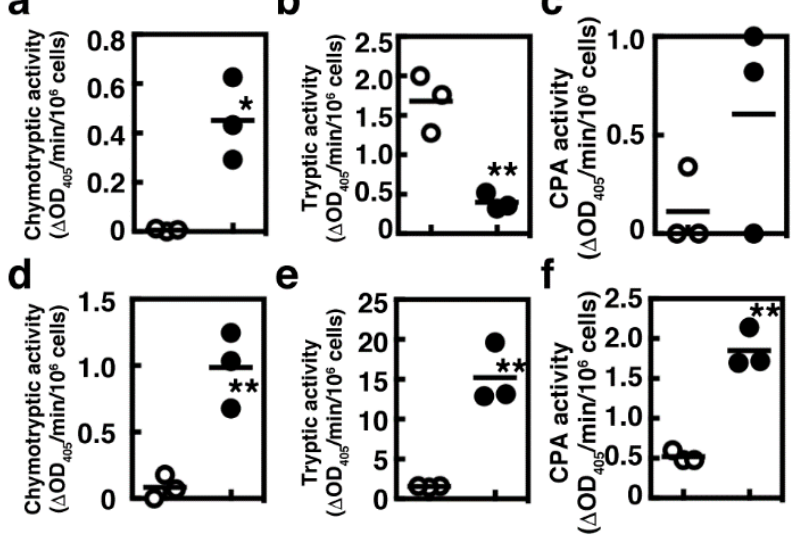

g

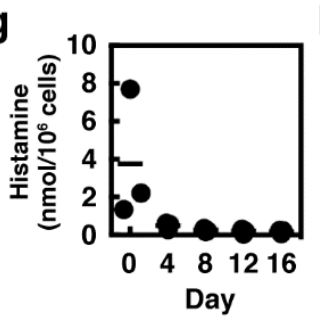

h
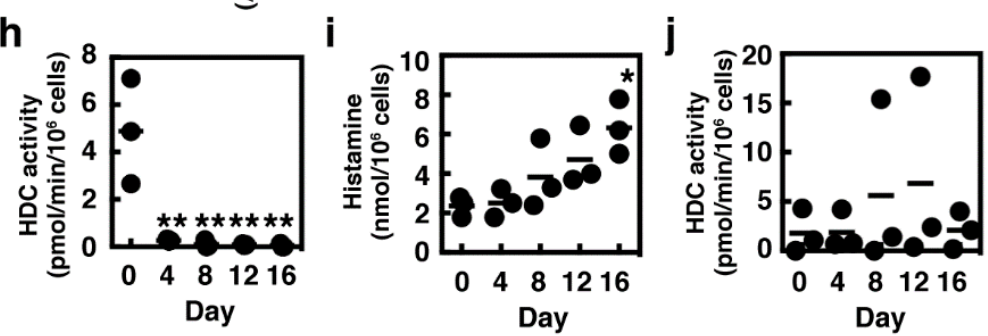

Figure 2. (a-c) Enzymatic activities of chymase (a, and d), tryptase (b, and e), and carboxypeptidase A (c, and f) were measured in BMMCs (open circles, a-f) and in MCs cultured in the presence of IL-9 and SCF for 12 days (closed circles, a, b, and c) and in MCs co-cultured with Swiss 3T3 fibroblasts in the presence of IL-9 and SCF for 16 days (closed circles, $d, e$, and f). Statistical analysis was performed using Student's t test. Values with ${ }^{*} p<0.05$ and ${ }^{* *} p<0.01$ are regarded as significant. (g-j) Cellular contents of histamine ( $g$ and $\mathrm{i}$ ) and enzymatic activities of HDC (h and $\mathrm{j}$ ) were measured respectively in MCs cultured in the presence of IL-9 and SCF ( $g$ and $h$ ) and in MCs co-cultured with Swiss 3T3 fibroblasts in the presence of IL-9 and SCF (i and j). Statistical analysis was performed using one-way ANOVA with Dunnett test. Values with ${ }^{*} p<0.05$ and ${ }^{* *} p<0.01$ are regarded as significant (compared with Day-0).
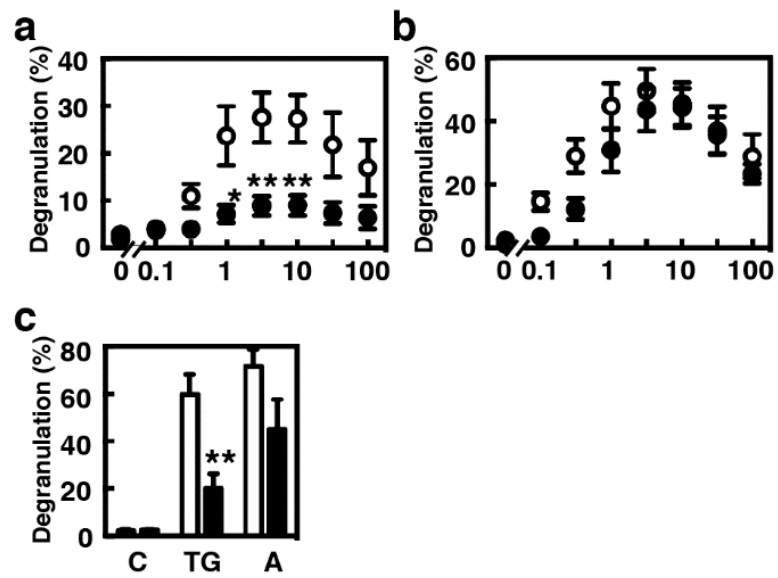

Figure 3. (a, b) BMMCs (open circles) or MMC-like MCs (Day-12, closed circles) were sensitized with $10 \mathrm{ng} / \mathrm{ml}$ (a) or $1 \mu \mathrm{g} / \mathrm{ml}$ (b) anti-TNP IgE (clone IgE-3) for $3 \mathrm{hr}$ at $37^{\circ} \mathrm{C}$. The cells were twice washed and stimulated with the indicated concentrations of the antigen (TNP-conjugated BSA). The levels of degranulation were determined by measuring the enzymatic activity of $\beta$-hexosaminidase. Values are presented as the means $\pm \operatorname{SEM}(n=4)$. Multiple comparisons were performed using two-way ANOVA with the Sidak test. Values with ${ }^{*} p<0.05$ and ${ }^{* *} p<0.01$ are regarded as significant. (c) BMMCs (open columns) or MMCs (closed columns) were stimulated without $(C$, vehicle) or with $300 \mathrm{nM}$ thapsigargin (TG) or $1 \mu \mathrm{M}$ A23187 (A). The levels of degranulation were determined by measuring the enzymatic activity of $\beta$-hexosaminidase. Values are presented as the means $\pm \operatorname{SEM}(n=4)$. Statistical analysis was performed using Student's $t$ test. A value with ${ }^{* *} p<0.01$ is regarded as significant. 


\subsection{Degranulation of MMC-like MCs in response to ATP}

Increased concentrations of ATP are often found in injured tissues and inflammatory sites. Several recent studies have indicated the significance of ATP-mediated activation of tissue mast cells [19]. Remarkable levels of degranulation $(>50 \%)$ were found in BMMCs when they were stimulated with $0.3 \mathrm{mM}$ ATP (Fig. 4a). Such prominent responses were not observed in MMC-like MCs. We investigated the mRNA expression levels of several $\mathrm{P}_{2} \mathrm{X}$ receptor subtypes that have been previously reported to be expressed in mast cells [20]. Moderate and high levels of expression of P2rx1, P2rx4, and $P 2 r x 7$, and very low levels of expression of $P 2 r x 3$ were detected both in BMMCs and in MMClike MCs (Fig. 4b-4e). An increasing tendency of $P 2 r x 7$ expression was found in MMC-like MCs.

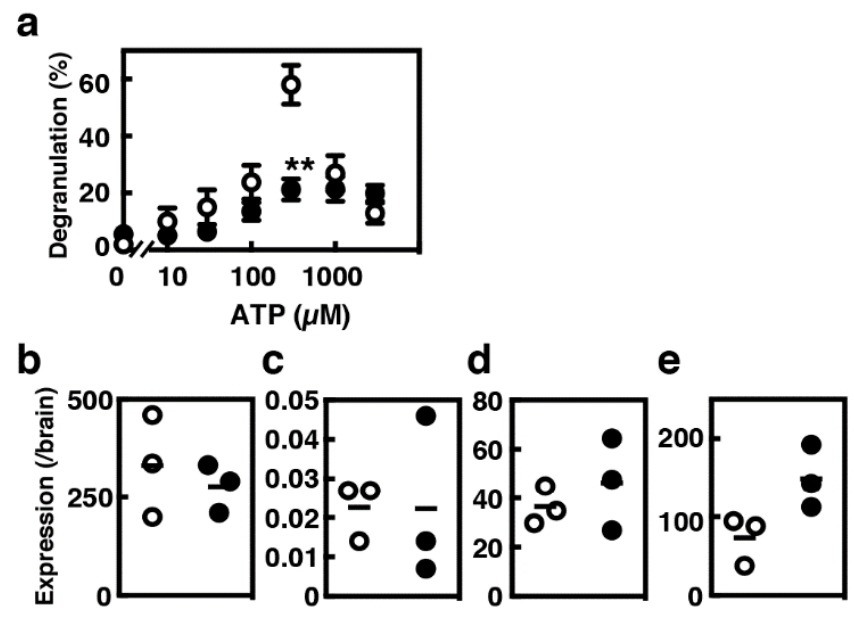

Figure 4. (a) BMMCs (open circles) and MMC-like MCs (Day-12, closed circles) were stimulated with the indicated concentrations of ATP. The levels of degranulation were determined by measuring the enzymatic activity of $\beta$-hexosaminidase. Values are presented as the means $\pm \operatorname{SEM}(n=4)$. Multiple comparisons were performed using two-way ANOVA with the Sidak test. A value with ${ }^{* *} p<0.01$ is regarded as significant. (b-e) The levels of mRNA expression of P2rx1 (b), P2rx3 (c), P2rx4 (d), and P2rx7 (e) in BMMCs (open circles) and MMCs (closed circles) were measured by quantitative RT-PCR.
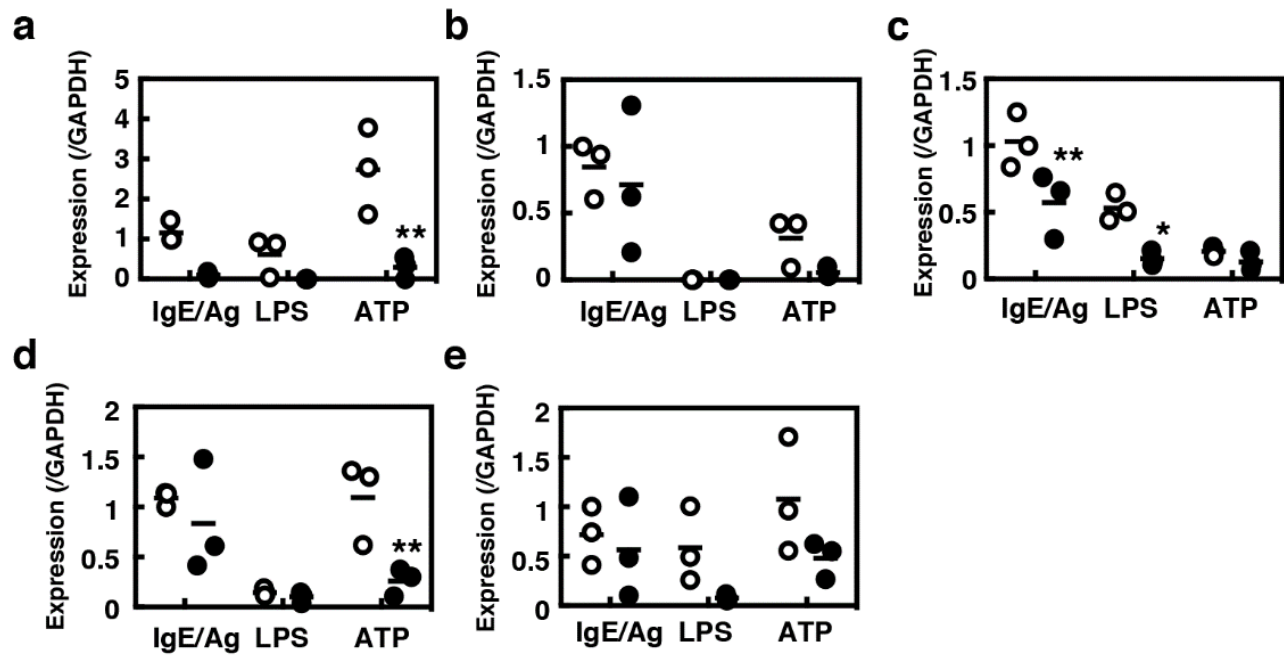

Figure 5. BMMCs (open circles) or MMC-like MCs (Day-12, closed circles) were sensitized with 1 $\mu \mathrm{g} / \mathrm{ml}$ anti-TNP IgE (clone IgE-3) for $3 \mathrm{hr}$ at $37^{\circ} \mathrm{C}$. The cells were twice washed and stimulated with the antigen (100 ng/ml, TNP-conjugated BSA) for $1 \mathrm{hr}$ (IgE/Ag). In parallel, BMMCs (open circles) or MMC-like MCs (Day-12, closed circles) were stimulated with LPS $(1 \mu \mathrm{g} / \mathrm{ml})$ or ATP $(1 \mathrm{mM})$ for $1 \mathrm{hr}$ at $37^{\circ} \mathrm{C}$. Expression levels of mRNA of a series of cytokines (a, IL-4, b, IL-5, c, IL-6, d, IL-13, and e, TNF- $\alpha$ ) were determined by quantitative RT-PCR. Statistical significance for comparison between 
BMMCs and MMC-like MCs was determined by unpaired Student's t-test. Values with * $p<0.05$ and ${ }^{* *} p<0.01$ are regarded as significant.

\subsection{Induction of the inflammatory cytokine gene expression in MMC-like MCs}

Mast cells are known to be the sources of a wide variety of cytokines. We compared the cytokine gene induction profiles between in BMMCs and in MMC-like MCs, such as IL-4, -5, -6, -13, and TNF$\alpha$ (Fig. 5). Overall, MMC-like MCs were found to be poor producers of these cytokines in comparison with BMMCs. MMC-like MCs were found to be incapable of IL-4 synthesis. Lipopolysaccharide (LPS) could induce the expression of pro-inflammatory cytokines, such as IL- 6 and TNF- $\alpha$ in BMMCs, whereas it could only induce marginal levels of IL-6 in MMC-like MCs. It is noteworthy that MMClike MCs had potentials to produce IL-5, IL-6, IL-13, and TNF- $\alpha$ upon IgE-mediated antigen stimulation.

\section{Discussion}

We characterized a novel bone marrow-derived cultured mast cell model, which partly reflected the nature of newly recruited murine intestinal mast cells. Parasite infections or oral allergen-induced immediate responses cause drastic changes in the intestinal mucosa, whereas it remains largely unknown how local mast cells adapt themselves to these changes. We focused on the roles of SCF and IL-9, both of which were found to have major impacts on newly recruited intestinal mast cells. Accumulating evidence suggest that a large number of mast cells should be recruited into the intestinal tracts and activated mast cells should play critical roles in pathology of inflammatory bowel diseases (IBD) and irritable bowel syndrome (IBS) [21-25], indicating that the characterization of intestinal mast cells should contribute to development of novel therapies for these chronic inflammatory diseases.

We previously found significant increases in histamine storage in BMMCs co-cultured with Swiss 3T3 fibroblasts in the presence of SCF [16]. SCF alone was found to have a potential to induce histamine synthesis in BMMCs [26]. Here histamine synthesis was abolished in the presence of SCF and IL-9, suggesting that IL-9 should be a potent suppressor of histamine synthesis. Histamine could profoundly affect the intestinal homeostasis through multiple pathways. It promotes increased vascular permeability and epithelial ion transports by acting on the $\mathrm{H}_{1}$ receptors $[27,28]$ and recruited neutrophils by acting on the $\mathrm{H}_{4}$ receptors [29]. Forward et al. demonstrated in vitro that histamine could attenuate the suppressor functions of $\mathrm{CD} 4{ }^{+} \mathrm{CD} 25^{+} \mathrm{T}$ regulatory cells by acting on the $\mathrm{H}_{1}$ receptors [30]. IL-9 may adequately control the intestinal environment through limiting the effects of mast cell-derived histamine. Interestingly, contact with fibroblasts was found to cancel the effects of IL-9. Migration of newly recruited mast cells in the intestinal tissues may stimulate histamine synthesis and promote further inflammatory responses (Fig. 6).

IL-9 was found to induce the expression of Mcpt1 and Mcpt2 [13], which was often found during parasite infections and oral allergen-induced anaphylaxis [31,32]. Our findings are consistent with these findings. The gene targeted mice lacking Mcpt1 exhibited delayed expulsion of Trichinella spiralis, but not that of Nippostrongylus brasiliensis [33]. Transcriptional induction of Mcpt1 at the early phase should be required for efficient expulsion of Trichinella spiralis. Recently, mucosal mast cells were found to damage the epithelial barrier through release of Mcpt1 upon Candida albicans infection [34]. We noticed that tryptic activity was significantly decreased in the presence of SCF and IL-9 whereas this trend was entirely reversed by co-culture with fibroblasts. This strict regulation of tryptase activity might reinforce the hypothesis that migration of recruited mast cells should regulate the intestinal epithelial integrity. In the jejunum of Trichinella spiralis-infected mice, Mcpt2+ mast cells were accumulated in the mucosal layer at the early phase and Mcpt2+, Mcpt $6^{+}$mast cells were detected at the recovery phase [32]. Mast cells recruited in the intestinal tissues upon parasite infection were often resident after its complete expulsion and were involved in pathogenic changes of the epithelial integrity. The gene targeted mice lacking Mcpt6 exhibited less severe pathology than the wild type mice in sodium dextran sulfate- and trinitrobenzene sulfonic acid (TNBS)-induced colitis model [35], indicating that Mcpt6 should be involved in disruption of the epithelial integrity. 
A variety of cells were found to be involved in recruiting mast cells through the release of IL-9. CD4+ IL-9 producing T cells (Th9) plays critical roles in mast cell accumulation in allergic lung inflammation [36]. In the tolerant allografts, $\mathrm{CD} 4^{+} \mathrm{CD} 25^{+} \mathrm{Foxp} 3^{+}$regulatory $\mathrm{T}$ cells were found to recruit mast cells through production of IL-9 [37]. Interestingly, mast cell itself was found to be the source of IL-9, which was augmented by lipopolysaccharide [38-41]. These findings raised a possibility that the number of intestinal mast cells should be drastically increased via the positive feedback loop.

We characterized the stimulated mediator release of MMC-like MCs in comparison with BMMCs. BMMCs were found to be more sensitive to lower concentrations of $\operatorname{IgE}$ and the other secretagogues than MMC-like MCs. Kurashima et al. demonstrated that extracellular ATP should play critical roles in the pathology of TNBS-induced colitis model by acting on $\mathrm{P}_{2} \mathrm{X}_{7}$ purinoreceptors in intestinal mast cells [42]. In our system, ATP induced expression of IL-4 and IL-13 in BMMCs whereas little or no induction of cytokine genes were observed in MMC-like MCs, raising a possibility that mast cell-derived inflammatory cytokines should function at very early stage of inflammation.

We here established a novel culture model, which might be useful for investigation of spatiotemporal changes of the newly recruited intestinal mast cells.

BMMC
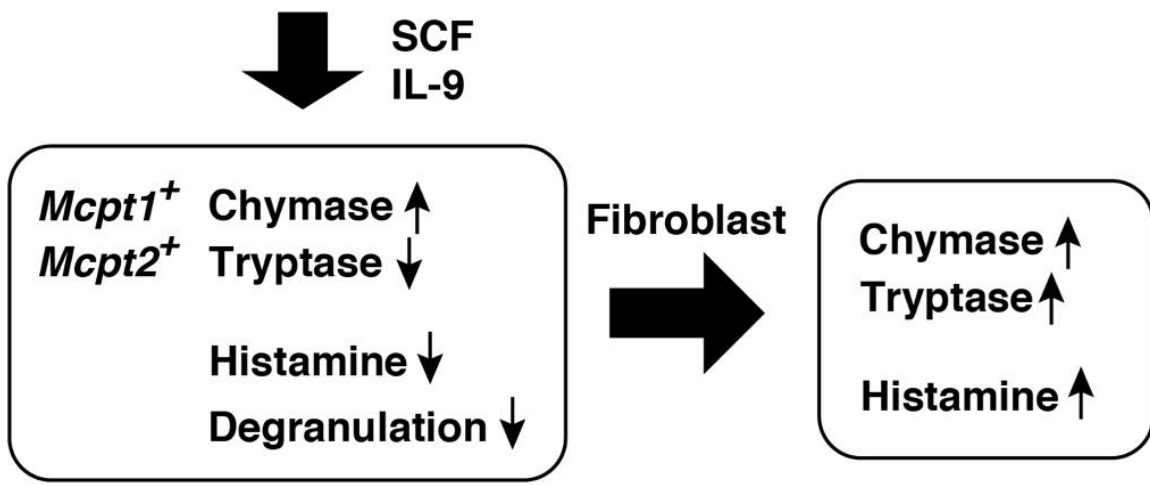

\section{MMC-like MC}

Figure 6. Schematic presentation of this study.

\section{Materials and Methods}

\subsection{Materials}

The following materials were commercially obtained from the sources indicated: ATP, an antidinitrophenyl IgE antibody (clone SPE-7), $p$-nitrophenyl- $\beta$-D-2-acetoamide-2-deoxyglucopyranoside, probenecid, and N-succinyl-Ala-Ala-Pro-Phe-pNA from Sigma-Aldrich (St. Louis, MO, USA), fetal bovine serum (FBS) from Thermo Fisher Scientifc (Waltham, MA, USA), an anti-trinitrophenyl IgE antibody (clone IgE-3), an FITC-conjugated rat anti-mouse IgE antibody, a phycoerythrin-conjugated rat anti-mouse CD117 antibody and Fc blocker (clone 2.4G2) from BD Biosciences (San Diego, CA, USA), trinitrophenyl bovine serum albumin (TNP-BSA) from LSL (Tokyo, Japan), H-D-Ile-Pro-ArgpNA (S-2288) from Chromogenix (Milano, Italy), N-(4-Methoxyphenylazoformyl)-Phe-OH potassium salt (M-2245) from Bachem AG (Bubendorf, Switzerland), thapsigargin from Merck Millipore (Billerica, MA, USA), Fura-2/AM from Dojindo Laboratories (Kumamoto, Japan), recombinant mouse IL-9 from PeproTech (Rocky Hill, NJ, USA), and recombinant mouse IL-3 from R \& D Systems (Minneapolis, MN, USA). Murine SCF was prepared by bacurovirus expression system with Sf9 cells according to the procedure described previously [16]. All other chemicals were commercial products of reagent grade. 


\subsection{Animals}

Specific-pathogen-free, 8 to 10-week-old male BALB/c mice were obtained from Japan SLC (Hamamatsu, Japan), and all mice were kept in a specific-pathogen-free animal facility at Okayama University. This study was approved by the Committee on Animal Experiments of Okayama University (Approved \#OKU- 2012218, and 2015040).

\subsection{Preparation of Bone Marrow-Derived Cultured Mast Cells}

Preparation of IL-3-dependent bone marrow-derived cultured mast cells (BMMCs) was performed as previously described using $10 \mathrm{ng} / \mathrm{ml}$ IL-3 in place of WEHI-3 conditioned medium [43]. Briefly, bone marrow cells obtained from male BALB/c mice were cultured in the presence of 10 ng/mL IL-3 for $\sim 30$ days. Greater than $95 \%$ of the cells exhibited metachromasy by acidic toluidine

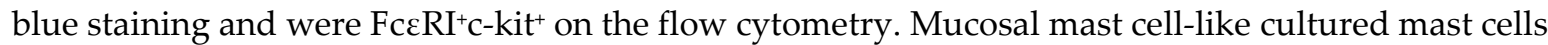
(MMC-like MCs) were prepared by the culture of BMMCs in the presence of $10 \mathrm{ng} / \mathrm{mL}$ IL-9 and 30 $\mathrm{ng} / \mathrm{mL}$ SCF. Subculture was performed every other day for 12 days. In some experiments, BMMCs were co-cultured with Swiss 3T3 cells, which were pretreated with mitomycin c as described previously [16], in the presence of $10 \mathrm{ng} / \mathrm{mL}$ IL-9 and $30 \mathrm{ng} / \mathrm{mL} \mathrm{SCF}$.

\subsection{Flowcytometry}

The cultured cells were treated with $10 \mu \mathrm{g} / \mathrm{mL}$ Fc blocker (clone 2.4G2) for $10 \mathrm{~min}$ at $4^{\circ} \mathrm{C}$ and then further incubated with $12.5 \mu \mathrm{g} / \mathrm{mL} \operatorname{IgE}$ (clone SPE-7) for $50 \mathrm{~min}$ at $4^{\circ} \mathrm{C}$. The surface expression levels of FceRI and c-kit were measured using FACSCalibur (BD Biosciences, San Diego, CA, USA) with an FITC-conjugated rat anti-mouse IgE antibody and a phycoerythrin-conjugated rat antiCD117 antibody.

\subsection{Measurement of granule protease activities}

Three categories of granule protease activity were measured using their specific substrates as described previously [16]. The cells were washed in phosphate-buffered saline (PBS), incubated in PBS containing $2 \mathrm{M} \mathrm{NaCl}$ and $0.5 \%$ Triton X-100 at $4{ }^{\circ} \mathrm{C}$ for $30 \mathrm{~min}$ and then centrifuged at $12,000 \times \mathrm{g}$ for $30 \mathrm{~min}$ at $4^{\circ} \mathrm{C}$. The resultant supernatants were subjected to granule protease assays. Chymotryptic activity was measured in $33.3 \mathrm{mM}$ Tris- $\mathrm{HCl}, \mathrm{pH} 8.3$ containing $3.3 \mathrm{mM} \mathrm{CaCl}_{2}$ and 0.3 $\mathrm{mM}$ N-succinyl-Ala-Ala-Pro-Phe-pNA. Tryptic activity was measured in $33 \mathrm{mM}$ Tris-HCl, $\mathrm{pH} 8.3$ containing $2 \mathrm{mM}$ S-2288. Carboxypeptidase A activity was measured in $33 \mathrm{mM}$ Tris- $\mathrm{HCl}, \mathrm{pH} 7.5$ containing $0.6 \mathrm{mM} \mathrm{M}-2245$. The enzymatic activity was determined by measuring $\mathrm{OD}_{405}$.

\subsection{Measurement of enzymatic activity of histidine decarboxylase}

The cultured cells were homogenized in the lysis buffer $(10 \mathrm{mM}$ potassium phosphate, $\mathrm{pH} 6.8$ containing $10 \mathrm{mM} \mathrm{KCl}, 1.5 \mathrm{mM} \mathrm{MgCl}$, $1 \mathrm{mM}$ EDTA, $1 \mathrm{mM}$ EGTA, $0.2 \mathrm{mM}$ dithiothreitol, $0.01 \mathrm{mM}$ pyridoxal 5'-phosphate, $0.2 \mathrm{mM}$ phenylmethylsulfonylfluoride, $0.1 \mathrm{mM}$ benzamidine, $10 \mu \mathrm{g} / \mathrm{mL}$ aprotinin, $10 \mu \mathrm{g} / \mathrm{mL}$ leupeptin, $10 \mu \mathrm{g} / \mathrm{ml} \mathrm{E}-64,1 \mu \mathrm{g} / \mathrm{mL}$ pepstatin A, and $0.1 \%$ Triton $\mathrm{X}-100$ ) and centrifuged at $10,000 \times \mathrm{g}$ for $30 \mathrm{~min}$ at $4^{\circ} \mathrm{C}$. The resultant supernatant was incubated in the assay buffer $(0.1 \mathrm{M}$ potassium phosphate, $\mathrm{pH} 6.8$ containing $0.2 \mathrm{mM}$ dithiothreitol, $0.01 \mathrm{mM}$ pyridoxal 5 'phosphate, $2 \%$ polyethylene glycol $\# 300,0.2 \mathrm{mM}$ aminoguanidine, and $0.8 \mathrm{mM}$ L-histidine) at $37^{\circ} \mathrm{C}$ for $4 \mathrm{hr}$. The reaction was stopped by adding perchloric acid (3\%). Histamine was fluorometrically measured by HPLC with a cation exchange column, WCX-1 (Shimadzu, Kyoto, Japan), after derivatization with $o$-phthalaldehyde [44].

\subsection{Measurement of Degranulation}

The cultured cells were suspended in PIPES-buffer ( $25 \mathrm{mM}$ PIPES-NaOH, pH 7.4 containing 125 $\mathrm{mM} \mathrm{NaCl}, 2.7 \mathrm{mM} \mathrm{KCl}, 1 \mathrm{mM} \mathrm{CaCl}$, $5.6 \mathrm{mM}$ glucose, and $0.1 \%$ bovine serum albumin), and then stimulated for $30 \mathrm{~min}$ at $37^{\circ} \mathrm{C}$. They were centrifuged at $800 \times \mathrm{g}$ at $4^{\circ} \mathrm{C}$ for $5 \mathrm{~min}$ to obtain the supernatants (extracellular fractions, E). The resultant pellets were resuspended in PIPES-buffer 
containing $0.5 \%$ Triton X-100 and were centrifuged at $10,000 \times \mathrm{g}$ for $10 \mathrm{~min}$ to obtain the supernatants (cell-associated fractions, C). Degranulation was evaluated by measuring enzyme activity of a granule enzyme, $\beta$-hexosaminidase, in each fraction, using the specific substrate, $p$-nitrophenyl- $\beta$-D2-acetoamide-2-deoxyglucopyranoside $(3.4 \mathrm{mM})$. The reactions were performed in $67 \mathrm{mM}$ citrate, $\mathrm{pH}$ 4.5. The amounts of p-nitrophenol were determined by measuring OD405. The percentages of degranulation were calculated; $\mathrm{E} /(\mathrm{C}+\mathrm{E}) \times 100(\%)$.

\subsection{Quantitative RT-PCR}

Total RNAs were extracted from the splenocytes using NucleoSpin RNA Kit (TaKaRa Bio Inc., Kusatsu, Japan) and reverse transcribed using PrimeScript ${ }^{\mathrm{TM}}$ RT Reagent Kit (TaKaRa Bio Inc.). First strand DNAs were subjected to quantitative PCR using KOD SYBR qPCR Mix (TOYOBO, Osaka, Japan) or SYBR Green PCR Master Mix (Thermo Fisher Scientific) with the specific primer pairs as follows. Mcpt1: 5'-GCA CTT CTC TTG CCT TCT GG-3', 5'-TAA GGA CGG GAG TGT GGT CT-3', Mcpt2: 5'-GCA CTT CTT TTG CCT TCT GG-3', 5'-TAA GGA CGG GAG TGT GGT TT-3', Mcpt5: 5'AGA ACT ACC TGT CGG C-3', 5'-GTC GTG GAC AAC CAA AT-3', Cpa3: 5'-GAT GTC TCG TGG GAC T-3', 5'-GCC GTA GAT GTA ACG GG-3', Hdc: 5'-TGC ACG CCT ACT ATC CTG CTC TTA C3', 5'-TCT GTG CAA GCT GGG CTA GAT G-3', Ptgr 1 : 5'-CAT CGT GAA TCG GTG G-3', Il4: 5'-TCG GCA TTT TGA ACG AGG TC-3', 5'-GAA AAG CCC GAA AGA GTC TC-3', Il5: 5' - ATG GAG ATT CCC ATG AGC AC-3', 5'-GTC TCT CCT CGC CAC ACT TC-3', IL6: 5'-TGG AGT CAC AGA AGG AGT GGC TAA G-3', 5'-TCT GAC CAC AGT GAG GAA TGT CCA C-3', Il13: 5' - CAG CTC CCT GGT TCT CTC AC-3', 5'-CCA CAC TCC ATA CCA TGC TG-3', Tnf: 5'-AAG CCT GTA GCC CAC GTC GTA-3', 5'-GGC ACC ACT AGT TGG TTG TCT TTG-3', P2rx 1 : 5'-CCA GGA CTT CCG AAG CCT TGC-3', 5'-AGA ACT GTG GCC ACT CCA AAG ATG-3', P2rx3: 5'-TCT TGC ACG AGA AGG CCT ACC AA-3', 5'-GAT CTC ACA GGT CCG ACG GAC A-3', P2rx4: 5'-GTG ACG TCA TAG TCC TCT ACT GT-3', 5'-TGC TCG TAG TCT TCC ACA TAC TT-3', P2rx7: 5'-AGC CTG TTA TCA GCT CCG TGC A-3', 5'-TCA GGA CAC AGC GTC TGC ACT T-3', and Gapdh: 5'-TGT GTC CGT CGT GGA TCT GA-3', 5'-TTG CTG TTG AAG TCG CAG GAG-3'

\subsection{Statistics}

Statistical significance for comparison between two groups was determined by unpaired Student's t-test. Statistical significance for comparisons among multiple groups was determined using one-way ANOVA. Additional comparisons were made with Dunnett multiple comparison test for comparison with the control groups or Tukey-Kramer multiple comparison test for all pairs of column comparison.

Author Contributions: Conceptualization, K.F. and S.T.; investigation, A.K., T.K., and S.Y.; writing-original draft preparation, A.K., T.K., S.T.; writing-review and editing, K.F. and S.T.; project administration, S.T.; funding acquisition, S.T.

Funding: This research was funded by grants from the JSPS KAKENHI Grant Number 23590077 and 16K08231.

Conflicts of Interest: The authors declare no conflict of interest.

\section{Abbreviations}

$\begin{array}{ll}\text { ANOVA } & \text { Analysis of variance } \\ \text { BMMC } & \text { IL-3-dependent bone marrow-derived cultured mast cell } \\ \text { FBS } & \text { Fetal bovine serum } \\ \text { MMC-like MC } & \text { Mucosal mast cell-like mast cell } \\ \text { PCR } & \text { Polymerase chain reaction } \\ \text { SCF } & \text { Stem cell factor (c-kit ligand) }\end{array}$

\section{References}

1. Kitamura, Y. Heterogeneity of mast cells and phenotypic changes between subpopulations. Annu. Rev. Immunol., 1989, 7, 59-76, 10.1146/annurev.iy.07.040189.000423. 
2. Galli, S.J.; Borregaard, N.; Wynn, T.A. Phenotypic and functional plasticity of cells of innate immunity: macrophages, mast cells and neutrophils. Nat. Immunol., 2011, 12, 1035-1044, 10.1038/ni.2109.

3. Galli, S.J.; Grimbaldeston, M.; Tsai, M. Immunomodulatory mast cells: negative, as well as positive, regulators of immunity. Nat. Rev. Immunol., 2008, 8, 478-486, 10.1038/nri2327.

4. Woodbury, R.G.; Miller, H.R.; Huntley, J.F.; Newlands, G.F.; Palliser AC.; Wakelin D. Mucosal mast cells are functionally active during spontaneous expulsion of intestinal nematode infections in rat. Nature, 1984, 312, 450-452, 10.1038/312450a0.

5. Bischoff, S.C. Role of mast cells in allergic and non-allergic immune responses: comparison of human and murine data. Nat. Rev. Immunol., 2007, 7, 93-104, 10.1038/nri2018.

6. Albert-Bayo, M.; Paracuellos, I.; González-Castro, A.M.; Rodriguez-Urrutia, A.; Rodríguez-Lagunas, M.J.; Alonso-Cotoner, C.; Santos, J.; Vicario, M. Intestinal mucosal mast cells: key modulators of barrier function and homeostasis. Cells, 2019, 8, E135, 10.3390/cells8020135.

7. Hültner, L.; Druez, C.; Moeller, J.; Uyttenhove, C.; Schmitt, E.; Rüde, E.; Dörmer, P.; van Snick, J. Mast cell growth-enhancing activity (MEA) is structurally related and functionally identical to the novel mouse $\mathrm{T}$ cell growth factor P40/TCGFIII (interleukin 9). Eur. J. Immunol., 1990, 20, 1413-1416, 10.1002/eji.1830200632.

8. Faulkner, H.; Humphreys, N.; Renauld, J.C.; Van Snick, J.; Grencis, R. Interleukin-9 is involved in host protective immunity to intestinal nematode infection. Eur. J. Immunol., 1997, 27, 2536-2540, 10.1002/eji.1830271011.

9. Godfrained, C.; Louahed, J.; Faulkner, H.; Vink, A.; Warnier, G.; Grencis, R.; Renauld, J.C. Intraepithelial infiltration by mast cells with both connective tissue-type and mucosal-type characteristics in gut, trachea, and kidneys of IL-9 transgenic mice. J. Immunol., 1998, 160, 3989-3996.

10. Faulkner, H.; Renauld, J.C.; Van Snick, J.; Grencis, R.K. Interleukin-9 enhances resistance to the intestinal nematode Trichuris muris. Infect. Immun., 1998, 66, 3832-3840.

11. Townsend, J.M.; Fallon, G.P.; Matthews, J.D.; Smith, P.; Jolin, E.H.; McKenzie, N.A. IL-9-deficient mice establish fundamental roles for IL-9 in pulmonary mastocytosis and goblet cell hyperplasia but not $\mathrm{T}$ cell development. Immunity, 2000, 13, 573-583, 10.1016/s1074-7613(00)00056-x.

12. Osterfeld, H.; Ahrens, R.; Strait, R.; Finkelman, F.D.; Renauld, J.C.; Hogan, S.P. Differential roles for the IL9/IL-9 receptor a-chain pathway in systemic and oral antigen-induced anaphylaxis. J. Allergy Clin. Immunol., 2010, 125, 469-476, 10.1016/j.jaci.2009.09.054.

13. Eklund, K.K.; Ghildyal, F.; Austen, K.F.; Stevens, R.L. Induction by IL-9 and suppression by IL-3 and IL-4 of the levels of chromosome 14-derived transcripts that encode late-expressed mouse mast cell proteases. J. Immunol., 1993, 151, 4266-4273.

14. Lantz, C.S.; Boesiger, J.; Song, C.H.; Mach, N.; Kobayashi, T.; Mulligan, R.C.; Nawa, Y.; Dranoff, G.; Galli, S.J. Role for interleukin-3 in mast cell and basophil development and in immunity to parasites. Nature, 1998, 392, 90-93, 10.1038/32190.

15. Reber, L.L.; Marichal, T.; Galli, S.J. New models for analyzing mast cell functions in vivo. Trends Immunol., 2012, 33, 613-625, 10.1016/j.it.2012.09.008

16. Takano, H.; Nakazawa, S.; Okuno, Y.; Shirata, N.; Tsuchiya, S.; Kainoh, T.; Takamatsu, S.; Furuta, K.; Taketomi, Y.; Naito, Y.; Takematsu, H.; Kozutsumi, Y.; Tsujimoto, G.; Murakami, M.; Kudo, I.; Ichikawa, A.; Nakayama, K.; Sugimoto, Y.; Tanaka, S. Establishment of the culture model system that reflects the process of terminal differentiation of connective tissue-type mast cells. FEBS Lett., 2008, 582, 1444-1450, 10.1016/j.febslet.2008.03.033.

17. Yamada, K.; Sato, H.; Sakamaki, K.; Kamada, M.; Okuno, Y.; Fukuishi, N.; Furuta, K.; Tanaka, S. Suppression of IgE-independent degranulation of murine connective tissue-type mast cells by dexamethasone. Cells, 2019, 8, 112-117, 10.3390/cells8020112.

18. Tsuchiya, S.; Tachida, Y.; Segi-Nishida, E.; Okuno, Y.; Tamba, S.; Tsujimoto, G.; Tanaka, S.; Sugimoto, Y. Characterization of gene expression profiles for different types of mast cells pooled from mouse stomach subregions by an RNA amplification method. BMC genomics, 2009, 10, 35, 10.1186/1471-2164-10-35.

19. Gao, Z.,G.; Jacobson, K.A. Purinergic signaling in mast cell degranulation and asthma. Front. Pharmacol., 2017, 8, 947, 10.3389/fphar.2017.00947.

20. Yoshida, K.; Ito, M.; Hoshino, Y.; Matsuoka, I. Effects of dexamethasone on purinergic signaling in murine mast cells: Selective suppression of P2X7 receptor expression. Biochem. Biophys. Res. Commun., 2017, 493, 1587-1593, 10.1016/j.bbrc.2017.10.020.

21. Andoh, A.; Deguchi, Y.; Inatomi, O.; Yagi, Y.; Bamba, S.; Tsujikawa, T.; Fujiyama, Y. Immunohistochemical study of chymase-positive mast cells in inflammatory bowel disease. Oncol. Rep., 2006, 16, 103-107. 
22. Han, W.; Lu, X.; Jia, X.; Zhou, T.; Guo, C. Soluble mediators released from PI-IBS patients' colon induced alteration of mast cells: involvement of reactive oxygen species. Dig. Dis. Sci., 2012, 57, 311-319, 10.1007/s10620-011-1897-2.

23. De Winter, B.Y.; van den Wijngaard, R.M.; de Jonge, W.J. Intestinal mast cells in gut inflammation and motility disturbances. Biochim. Biophys. Acta., 2012, 1822, 66-73, 10.1016/j.bbadis.2011.03.016.

24. Wouters, M.M; Vicario, M.; Santos, J. The role of mast cells in functional GI disorders. Gut, 2016, 65, 155168, 10.1136/gutjnl-2015-309151.

25. Bischoff, S.C. Mast cells in gastrointestinal disorders. Eur. J. Pharmacol., 2016, 778, 139-145, 10.1016/j.ejphar.2016.02.018.

26. Tsai, M.; Takeishi, T.; Thompson, H.; Langley, K.E.; Zsebo, K.M.; Metcalfe, D.D.; Geissler, E.N.; Galli, S.J. Induction of mast cell proliferation, maturation, and heparin synthesis by the rat c-kit ligand, stem cell factor. Proc. Natl. Acad. Sci. USA, 1991, 88, 6382-6386, 10.1073/pnas.88.14.6382.

27. Mortillaro, N.A.; Granger, D.N.; Kvietys, P.R.; Rutill, G.; Taylor, A.E. Effects of histamine and histamine antagonists on intestinal capillary permeability. Am. J. Physiol., 1981, 240, G381-G3886, 10.1152/ajpgi.1981.240.5.G381.

28. Keely, S.J.; Stack, W.A.; O'Donoghue, D.P.; Baird, A.W. Regulation of ion transport by histamine in human colon. Eur. J. Pharmacol., 1995, 279, 203-209, 10.1016/0014-2999(95)00156-f.

29. Wechsler, J.B.; Szabo, A.; Hsu, C.L.; Krier-Burris, R.A.; Schroeder, H.A.; Wang, M.Y.; Carter, R.G.; Velez, T.E.; Aguiniga, L.M.; Brown, J.B.; Miller, M.L.; Wershil, B.K.; Barrett, T.A.; Bryce, P.J. Histamine drives severity of innate inflammation via histamine 4 receptor in murine experimental colitis. Mucosal Immunol., 2018, 11, 861-870, 10.1038/mi.2017.121.

30. Forward, N.A.; Furlong, S.J.; Yang, Y.; Lin, T.J.; Hoskin, D.W. Mast cells down-regulate CD4 ${ }^{+}$CD25 $5^{+} \mathrm{T}$ reguratory cell suppressor function via histamine $\mathrm{H}_{1}$ receptor interaction. J. Immunol., 2009, 183, 3014-3022, 10.4049/jimmunol.0802509.

31. Forbes, E.E.; Groschwitz, K.; Abonia, J.P.; Brandt, E.B.; Cohen, E.; Blanchard, C.; Ahrens, R.; Seidu, L.; McKenzie, A.; Strait, R.; Finkelman, F.D.; Foster, P.S.; Matthaei, K.I.; Rothenberg, M.E.; Hogan, S.P. IL-9and mast cell-mediated intestinal permeability predisposes to oral antigen hypersensitivity. J. Exp. Med., 2008, 205, 897-913, 10.1084/jem.20071046.

32. Friend, D.S.; Ghildyal, N.; Gurish, M.F.; Hunt, J.; Hu, X.; Austen, K.F.; Stevens, R.L. Reversible expression of tryptases and chymases in the jejunum mast cells of mice infected with Trichinella spiralis. J. Immunol., 1998, 160, 5537-5545.

33. Knight, P.A.; Wright, S.H.; Lawrence, C.E.; Paterson, Y.Y.W.; Miller, H.R.P. Delayed expulsion of the Nematode Trichinella spiralis in mice lacking the mucosal mast cell-specific granule chymase, mouse mast cell protease-1. J. Exp. Med., 2000, 192, 1849-1856, 10.1084/jem.192.12.1849.

34. Renga, G.; Moretti, S.; Oikonomou, V.; Borghi, M.; Zelente, T.; Paolicelli, G.; Costantini, C.; De Zuani, M.; Villella, V.R.; Raia, V.; Del Sordo, R.; Bartoli, A.; Baldoni, M.; Renauld, J.C.; Sidoni, A.; Garaci, E.; Maiuri, L.; Pucillo, C.; Romani, L. IL-9 and mast cells are key players of Candida albicans commensalism and pathogenesis in the gut. Cell Rep., 2018, 23, 1767-1778, 10.1016/j.celrep.2018.04.034.

35. Hamilton, M.J.; Sinnamon, M.J.; Lyng, G.D.; Glickman, J.N.; Wang, X.; Xing, W.; Krilis, S.A.; Blumberg, R.S.; Adachi, R.; Lee, D.M.; Stevens, R.L. Essential role for mast cell tryptase in acute experimental colitis. Proc. Natl. Acad. Sci. USA, 2011, 108, 290-295, 10.1073/pnas.1005758108.

36. Sehra, S.; Yao, W.; Nguyen, E.T.; Glosson-Byers, N.L.; Akhtar, N.; Zhou, B.; Kaplan, M.H. TH9 cells are required for tissue mast cell accumulation during allergic inflammation. J. Allergy Clin. Immunol., 2015, 136, 433-440, 10.1016/j.jaci.2015.01.021e431.

37. Lu, L.F.; Lind, E.F.; Gondek, D.C.; Bennett, K.A.; Gleeson, M.W.; Pino-Lagos, K.; Scott, Z.A.; Coyle, A.J.; Reed, J.L.; Van Snick, J.; Strom, T.B.; Zheng, X.X.; Noelle, R.J. Mast cells are essentials intermediaries in regulatory T-cell tolerance. Nature, 2006, 442, 997-1002, 10.1038/nature05010.

38. Hültner, L.; Kölsch, S.; Stassen, M.; Kaspers, U.; Kremer, J.P.; Mailhammer, R.; Moeller, J.; Broszeit, H.; Schmitt, E. In activated mast cells, IL-1 up-regulates the production of several Th2-related cytokines including IL-9. J. Immunol., 2000, 164, 5556-5563, 10.4049/jimmunol.164.11.5556.

39. Stassen, M.; Arnold, M.; Hültner, L.; Müller, C.; Neudörfl, C.; Reineke, T.; Schmitt, E. Murine bone marrowderived mast cells as potent producers of IL-9: Costimulatory function of IL-10 and kit ligand in the presence of IL-1. J. Immunol., 2000, 164, 5549-5555, 10.4049/jimmunol.164.11.5549.

40. Stassen, M.: Müller, C.; Arnold, M.; Hültner, L.; Klein-Hessling, S.; Neudörfl, C.; Reineke, T.; Serfling, E.; Schmitt, E. IL-9 and IL-13 production by activated mast cells is strongly enhanced in the presence of 
lipopolysaccharide: NF-kappa B is decisively involved in the expression of IL-9. J. Immunol., 2001, 166, 43914398, 10.4049/jimmunol.166.7.4391.

41. Chen, C.Y.; Lee, J.B.; Liu, B.; Ohta, S.; Wang, P.Y.; Kartashov, A.V.; Mugge, L.; Abonia, J.P.; Barski, A.; Izuhara, K.; Rothenberg ME.; Finkelman FD.; Hogan SP.; Wang YH. Induction of interleukin-9-producing mucosal mast cells promotes susceptibility to IgE-mediated experimental food allergy. Immunity, 2015, 43, 788-802, 10.1016/j.immuni.2015.08.020.

42. Kurashima, Y.; Amiya, T.; Nohi, T., Fujisawa, K.; Haraguchi, T.; Iba, H.; Tsutsui, H.; Sato, S.; Nakajima, S.; Iijima, H.; Kubo, M.; Kunisawa, J.; Kiyono, H. Extracelluar ATP mediates mast cell-dependent intestinal inflammation through $\mathrm{P}_{2} \mathrm{X}_{7}$ purinoreceptors. Nat. Cummun., 2012, 3,1034, 10.1038/ncomms2023.

43. Tanaka, S.; Takasu, Y.; Mikura, S.; Satoh, N.; Ichikawa, A. Antigen-independent induction of histamine synthesis by immunoglobulin E in mouse bone marrow-derived mast cells. J. Exp. Med., 2002, 196, 229-235, 10.1084/jem.20012037.

44. Yamatodani, A.; Fukuda, H.; Wada, H.; Iwaeda, T.; Watanabe, T. High-performance liquid chromatographic determination of plasma and brain histamine without previous purification of biological samples: Cation-exchange chromatography coupled with post-column derivatization fluorometry. $J$. Chrmatogr., 1985. 344. 115-123, 10.1016/S0378-4347(00)82012-5. 